\title{
Dalla didattica epistolare alla didattica digitale. Tradizione e attualità dell'apprendimento a distanza del disegno
}

\author{
Michele Valentino \\ Enrico Cicalò \\ Marta Pileri
}

\section{Abstract}

La disciplina del disegno, in questa fase di crisi internazionale dovuta alla pandemia, si interroga sulle modalità di trasmissione della conoscenza. La didattica universitaria a distanza, divenuta, in questa fase, l'unica forma di condivisione del sapere, ha portato teorici e docenti del disegno a sviluppare nuove metodologie in grado di innescare nella mente dello studente un grado di consapevolezza sempre maggiore. II saggio intende offrire una panoramica della evoluzione storica dell'insegnamento a distanza, che avveniva anticamente tramite la forma della lettera e che nel Novecento, mediante i nuovi media, si trasforma in un sistema sempre più complesso ed efficace di implementazione della conoscenza. La rivoluzione avviene a partire dagli anni Novanta del secolo scorso, quando le reti informatiche creano una accelerazione degli strumenti di comunicazione del sapere. Questa profonda trasformazione della conoscenza e della trasmissione grazie alla rete e al digitale ha portato gli studiosi della comunicazione, delle scienze sociali e naturalmente del disegno e della rappresentazione a costruire nuove pratiche e nuove metodologie in grado di offrire un campo sempre più attivo e interagente di esperienze e di apprendimenti, in un sistema sempre più aperto e codificato che consente di costruire una conoscenza aumentata. In questa rivoluzione dei mezzi di trasmissione della conoscenza del disegno, devono essere implementate sia le esperienze laboratoriali in presenza sia quelle a distanza, in grado di costruire una comunità di apprendimento sempre più complessa.

Parole chiave

disegno, didattica, metodologie, media, evoluzione storica.

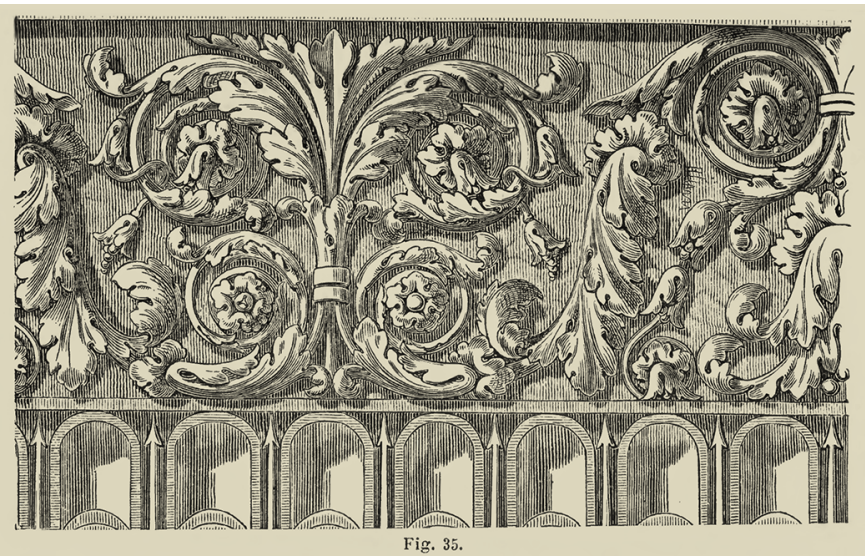




\section{Le tre generazioni della formazione a distanza}

La formazione a distanza ha come obiettivo quello di superare i limiti spazio-temporali tipici di quella in presenza. II suo impiego ha avuto una crescita influenzata dall'implementazione delle tecnologie della comunicazione. Questo tipo di formazione ha un vasto campo di applicazioni e si è servita di una grossa varietà di media in differenti contesti [Verduin 199/]. È ormai comunemente accolta la periodizzazione proposta da Donn Randy Garrison [Garrison 1985] e ripresa da Søren Nipper [Nipper 1989] delle tre generazioni della formazione a distanza.

La prima generazione - di origine ottocentesca - è legata alla corrispondenza postale. La seconda - riconducibile agli anni Sessanta e Settanta del Novecento - è collegata allo sviluppo delle tecnologie audiovisive. Mentre la terza si awale delle tecnologie e delle reti informatiche. Ma è proprio con l'emergenza pandemica che la formazione a distanza ha ricevuto una significativa spinta nel suo sviluppo e ha obbligato le diverse comunità di apprendimento ad adottarla a discapito di quella tradizionale.

La compresenza di modelli didattici, in presenza e a distanza, è testimoniata sin dall'antichità classica. Ne sono dimostrazione le lettere 'didattiche' tra Aristòtele e Alessandro Magno. Infatti, dopo il periodo di formazione fra il 343 e il 342 a.C., anni in cui su invito di Filippo II di Macedonia si occupò dell'educazione del giovane principe, Aristòtele dedicò una serie di opere ad Alessandro, la cui originalità è ancora controversa, come la Retorica ad Alessandro [Aristotele 2015] o la lettera Sulla politica delle città [Aristotele 20 I7]. Delineando così la presenza simultanea dell'istruzione peripatetica e di quella epistolare. Molto più vicina a noi, seppur non con un intento didattico ma con finalità di strutturare una conoscenza comune e un'aspirazione verso il rinnovamento profondo dell'arte, ritroviamo la corrispondenza fra Vasilij Vasil'evič Kandinskij e Arnold Schönberg, raccolta nel testo Musica e pittura [Schonberg 20I8]. Allo stesso modo Camillo Boito nell'opera I Principii del Disegno e gli Stili dell'Ornamento [Boito 1988], edita per la prima volta nel I 882, usa la forma epistolare rivolgendosi al suo amico immaginario Giovanni che lo invita a guidarlo nel nuovo incarico come insegnate di disegno. Nelle dodici lettere si rende evidente una metodologia didattica del disegno uguale a quella delle altre materie impartite nelle scuole primarie. A proposito di alcune osservazioni dell'amico nella seconda lettera Boito afferma: "L'insegnamento del disegno non è un insegnamento artistico [...] Non confondiamo la educazione del gusto con l'insegnamento del disegno. [...] || cominciamento dello studio del disegno è già più nobile assai, poiché l'occhio si collega intimamente all'intelligenza." [Boito, 1988, pp. 7-9].

In un tempo in cui gli spostamenti fra luoghi erano lentissimi, la scrittura epistolare ha rappresentato una straordinaria opportunità di comunicare conoscenze ed esperienze tramite una forma scritta che parlava al singolare. A differenza dei testi tradizionali in cui l'autore si rivolge a un'ampia platea di lettori e che ricerca nella scrittura un principio universale, la lettera contiene un messaggio privato che si carica delle complessità di interazione fra due soggetti. Ne consegue un alto grado di responsabilità nello scrivente che comunica informazioni e conoscenze a un soggetto specifico. La scrittura assume una valenza totalizzante. II cartiglio ha rappresentato il mezzo più importante per far viaggiare pensieri e idee attraverso la forma

Figg. I, 2. Camillo Boito, due delle tavole che accompagnano il testo delle lettere all'amico Giovanni [Boito 1882, pp. I96-197].
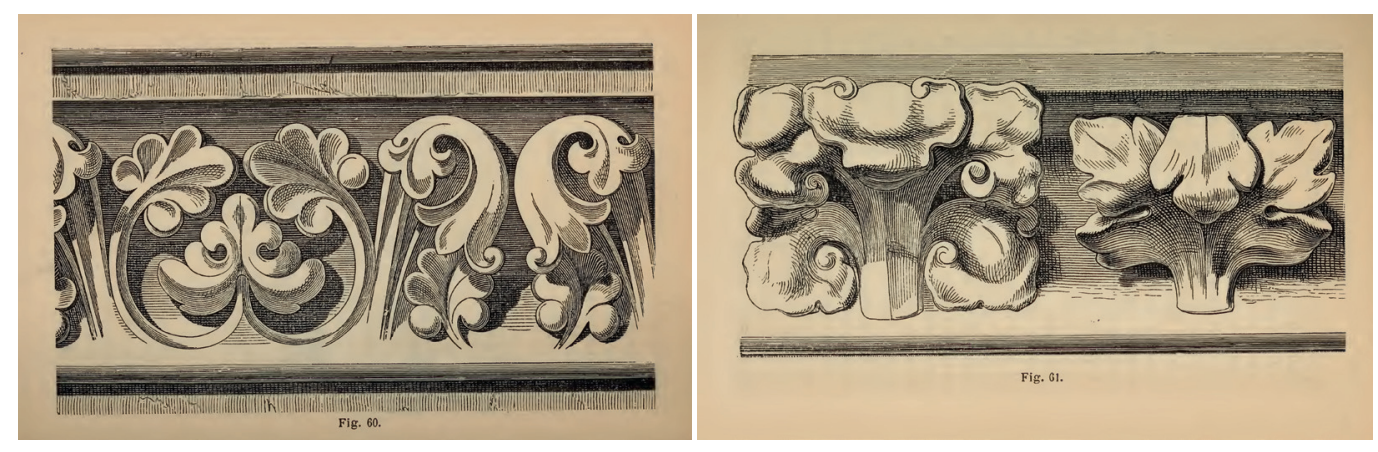
scritta, personale, dotata di una specifica calligrafia. Questa forma di apprendimento-insegnamento ricalca il modello del dialogo, che è la forma originaria della filosofia, ossia di una comunicazione fra due soggetti. ricordato che la prima formazione a distanza, che esula da quella epistolare, risale agli anni a cavallo fra Ottocento e Novecento, parallela allo sviluppo del sistema ferroviario. È in questo periodo che si assiste alla nascita dei primi corsi per corrispondenza che hanno come obiettivo principale quello di istruire tutti coloro che non hanno accesso a un'istituzione educativa, allora elitaria.

Ne sono esempio i corsi per corrispondenza dello sviluppatore del celebre sistema di stenografia Isaac Pitman ( 840 ), che aveva impostato il corso a distanza inviando testi per posta trascritti in stenografia su cartoline. Pochi anni più tardi la University of London, attraverso lo External Programme istituito nel I858, diede vita al primo corso universitario a distanza che ha portato ai più complessi International Programmes odierni [Tury Robinson 20 I5].

Non si può non citare Gli elementi del disegno (2009) di John Ruskin, edito nel I 857, pensato come un supporto alla didattica a distanza, con numerosi rimandi ai materiali didattici integrativi che l'allievo poteva consultare autonomamente. II manuale scritto per l'apprendimento dilettantistico del disegno è strutturato in tre lettere indirizzate genericamente al lettore [Cicalò 2020]. II teorico inglese, sin dalla prima lettera, rende note le intenzioni del libro:

"Caro Lettore, [...]. Se desideri soltanto possedere una piacevole abilità, e saper conversare con disinvoltura in materia di disegno, o svagare senza sforzo nelle ore vuote, non posso farci niente. Se invece vuoi imparare a disegnare per poter rappresentare in maniera chiara e utile immagini di cose che non si possono descrivere a parole, $[. .$.$] in questo caso sì che posso$ esserti utile, anzi, meglio ancora, mostrarti come progredire da solo." [Ruskin I857, pp. I, 2]. Questi primi esempi costituiscono un modello didattico di 'istruzionismo' unidirezionale da docente a discente.

Svariati programmi di formazione a distanza per corrispondenza postale si sono sviluppati durante la prima metà del Novecento. Un noto esempio italiano è rappresentato dall'istituzione della Scuola Radio Elettra nel 195I, intesa come centro di formazione professionale teorico-pratico orientato al mondo del lavoro.

Il cambio di prospettiva avviene negli anni Sessanta e Settanta del Novecento con l'ingresso dei nuovi media nella cultura di massa. La televisione introduce nelle case uno schermo, una finestra, che consente di abbattere le distanze, generando nuove narrazioni. L'arte, pensiamo al movimento Neo-Dada di Robert Rauschenberg, aveva stratificato su una tela i messaggi provenienti dai nuovi media in una narrazione simultanea di informazioni. È la video arte

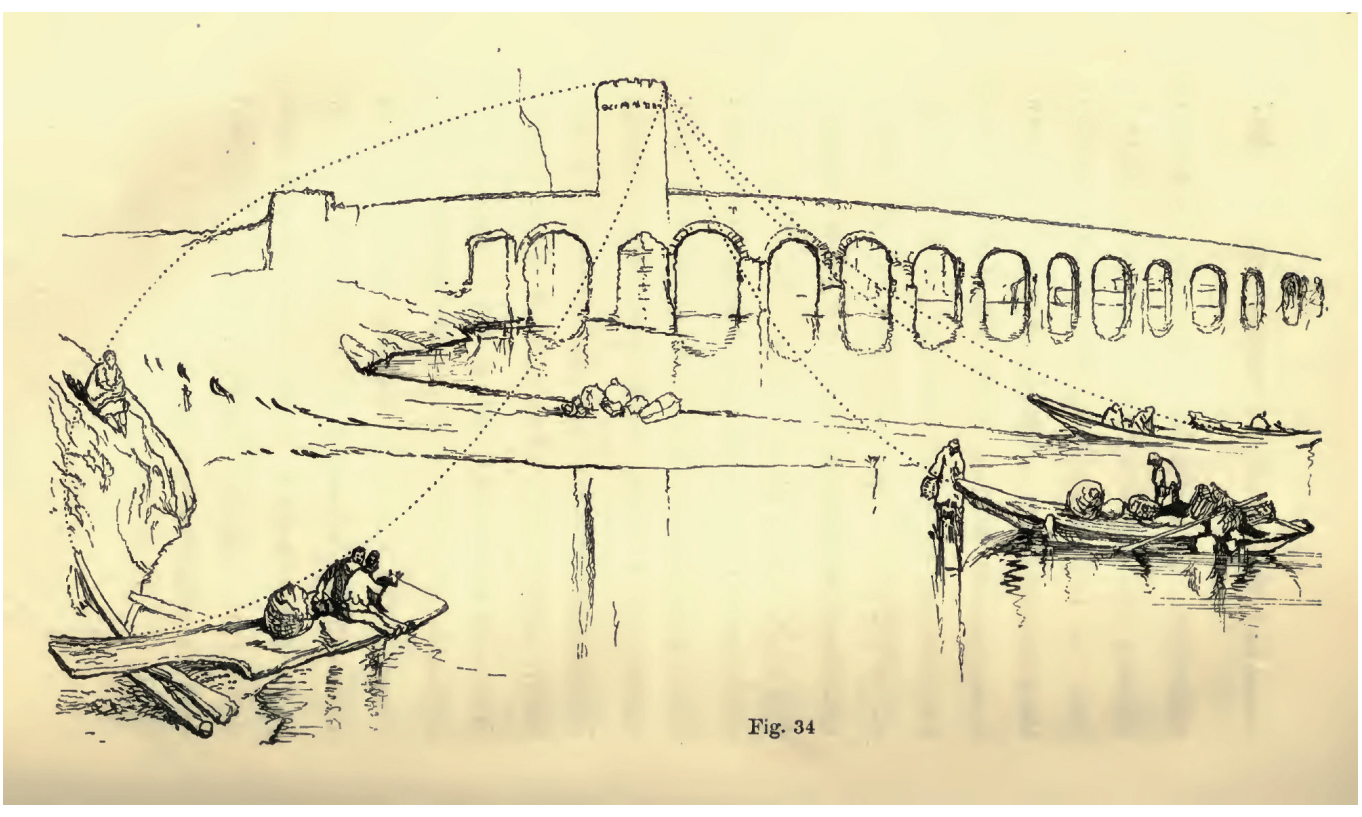


negli anni Settanta a rompere definitivamente i rapporti con i materiali tradizionali dell'arte, introducendo una visione politica che spingeva l'osservatore a prendere coscienza delle crisi del proprio tempo [Craft 20I2].

La formazione a distanza, tramite i nuovi media, diventa uno straordinario strumento di trasmissione delle conoscenze. II soggetto si trova immerso in una nuova profondità in grado di esaltare esperienze individuali.

È in questi anni che si sviluppano i primi programmi trasmessi, via radio e televisivamente, con l'intento di istruire le masse. Basti pensare al celebre programma Non è mai troppo tardi condotto dal maestro Alberto Manzi, mandato in onda dalla Rai (1960-1968). Lo scopo era di trasmettere un corso di istruzione primaria per persone analfabete, in un processo di inclusione e modernizzazione dell'intero Paese.

Nel tempo queste pratiche diventano sempre più sofisticate tramite una metodologia e una filosofia pedagogica incentrate sull'efficacia della comunicazione. Negli anni Novanta, le Università si fanno promotrici di programmi di formazione televisiva, trasmessi nel palinsesto notturno, pensiamo alla UniNettuno. Ne è un esempio il corso di Disegno e Architettura Tecnica con le lezioni video del professor Michele Inzerillo sulle basi della geometria descrittiva. Si assiste al passaggio dal modello didattico basato sull'istruzionismo' a quello del 'costruzionismo' interattivo [Pinotti 20 I6].

La rivoluzione digitale, negli anni Novanta, ha generato una accelerazione di trasmissione del sapere e dell'apprendimento. Sono disponibili nelle mani degli insegnanti vari strumenti in grado di chiarire i temi svolti, con la possibilità di scendere sempre più in profondità in una moltitudine di pieghe didattiche. Pensiamo alle innumerevoli risorse interattive disponibili sul Web. Tali sistemi si costruiscono in tempo reale e consentono un'implementazione di informazioni che si possono sommare progressivamente. A partire dal Duemila, le teorie del costruttivismo sociale vengono applicate agli ambienti virtuali cognitivi che generano sistemi multipli di conoscenza. Questi coinvolgono gli utenti in un sapere sempre più multidirezionale [Calvani 2000].

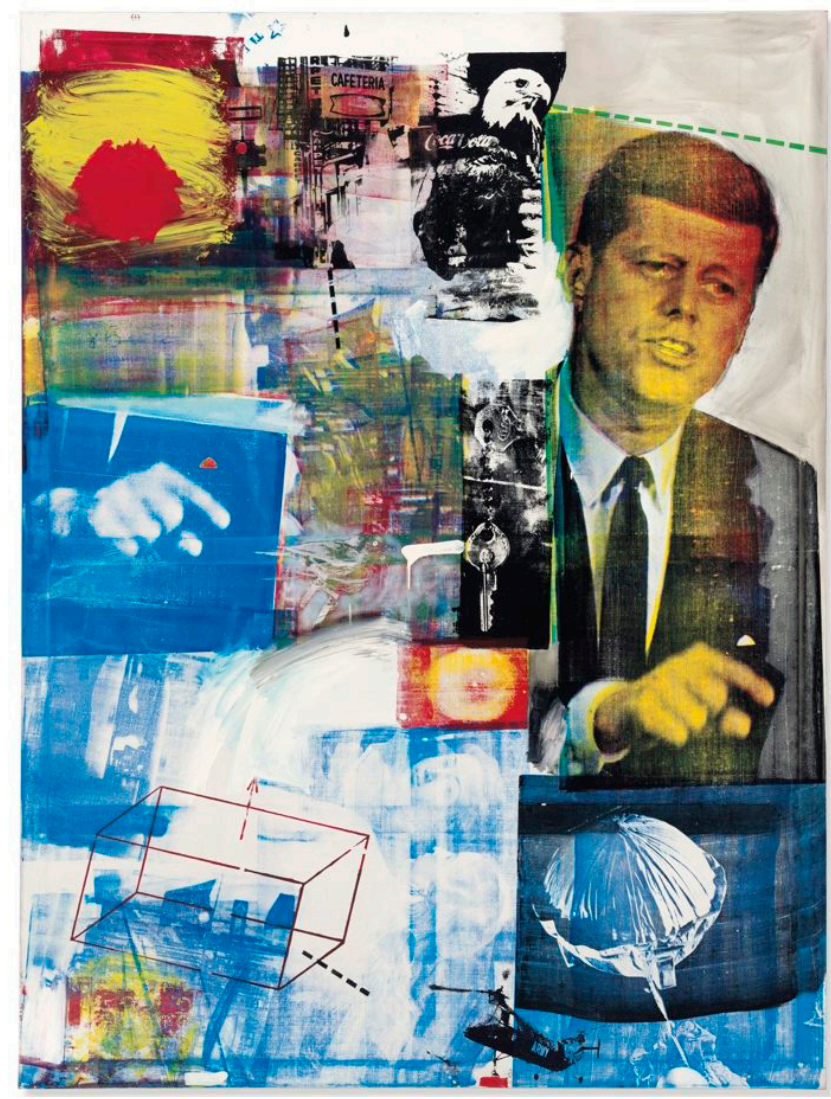




\section{Criticità e potenzialità della formazione a distanza}

Nella modernità il nucleo fondante della formazione avviene nel laboratorio, pensiamo alla scuola del Bauhaus (1919-1933) o deiVchutemas (1920-1927), dove la conoscenza si realizza in una esperienza diretta tra il maestro e gli studenti. II laboratorio è un luogo alchemico dove poter sperimentare la complessa rete di interrelazioni di esperienze tra un maestro 'riconosciuto' e studenti fortemente motivati [Bettinelli 1987].

Negli stessi anni, Benjamin capì che i mezzi riproduttivi delle immagini avrebbero inevitabilmente cambiato il tempo futuro. Nel suo libro, L'opera d'arte nell'epoca della sua riproducibilità tecnica (1974), intuì che le moderne tecniche della fotografia e del cinema avrebbero messo in crisi l'aura di autenticità dell'opera e offerto uno straordinario strumento di diffusione democratica della conoscenza.

Sappiamo che la storia ha vissuto momenti di crisi causati da guerre e pandemie che ne hanno minato le condizioni di prosperità, creando tensioni sociali, economiche e politiche. Tali condizioni di crisi generano nelle presenti nuove risposte nei campi della filosofia, della letteratura e dell'arte. Pensiamo ai movimenti artistici che si sviluppano durante il primo conflitto mondiale. Oggi, la pandemia obbliga a un ripensamento generale dei modi attraverso i quali si trasmettono le conoscenze.

L'insegnante deve essere in grado di chiarire e di comunicare un messaggio disciplinare esatto, preciso e trasmissibile. Rispetto alla didattica in presenza in cui l'interazione fisica dei corpi consente di esplicitare diverse espressioni verbali e corporee, quella a distanza si è dimostrata efficace nel momento in cui il docente capitalizza il tempo. La didattica a distanza ha creato un rapporto più stretto tra il docente e il singolo studente, generando in alcuni casi risultati migliori di quanto avveniva in presenza.

La didattica del disegno, con tutta la sua complessità semantica della comunicazione dei significati e dei messaggi, diventa un campo di azione in cui sperimentare nuove forme di trasmissione del sapere. L'esperienza della didattica a distanza, in una condizione di crisi, ha portato certamente il docente a interrogarsi sul fattore tempo.

II disegno consente di comunicare le sue qualità in un ambiente sempre più proteso alla complessità della realtà. La pandemia, generando una forma di isolamento, spinge l'individuo a raggiungere un grado di concentrazione e di puntualità che spesso la didattica frontale, proprio perché data per scontata, non consente di raggiungere.

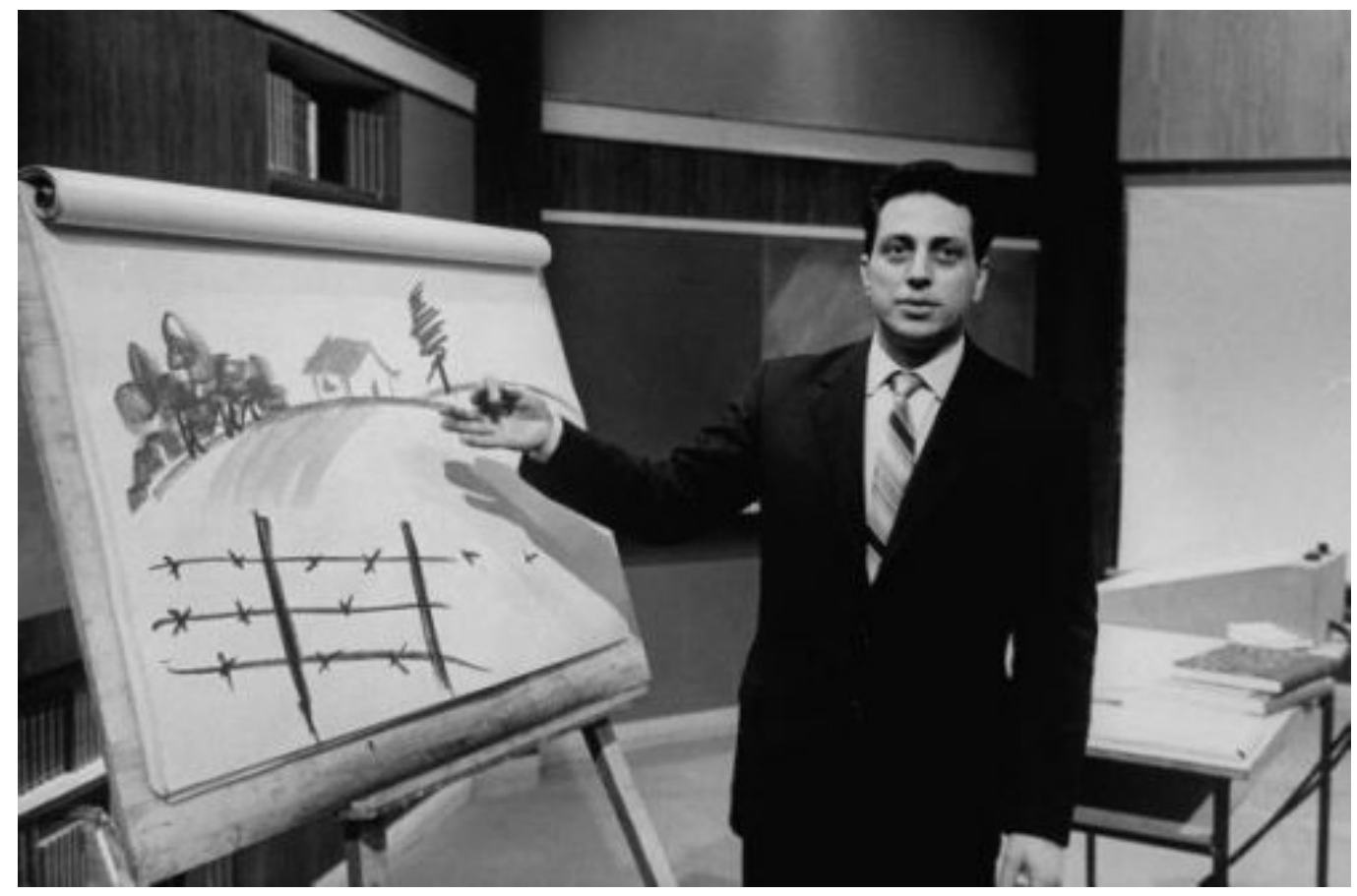


La possibilità da parte dello studente di poter accedere a lezioni su piattaforme digitali e di trovare sui canali virtuali tutorial, sempre più rispondenti alle esigenze individuali, ha creato uno straordinario ambiente di apprendimento. Si pensi alle varie lezioni disponibili sui canali YouTube che permettono di approfondire la conoscenza dei più svariati software per la rappresentazione digitale.

Ma come in ogni momento di crisi, si aprono nuovi interrogativi sul futuro. A questo proposito, la formazione legata alla disciplina del disegno deve interrogarsi sulle modalità e sulle prerogative disciplinari e metodologiche.

Fortunatamente, ad ogni momento di crisi è corrisposto nella storia un momento di rinascita. Una rinascita che quasi mai è fatta di un superamento del passato, ma di un recupero e di una contaminazione del tempo presente con quello futuro. Ne consegue che, superata la crisi pandemica, la disciplina del disegno possa interrogarsi sui propri statuti interni andando a potenziare le qualità che si sono sviluppate anche tramite la didattica a distanza. Bisogna integrare diversi mezzi di trasmissione del sapere: il laboratorio come momento esperienziale e la didattica tramite video che si sforza in modo dialogico di parlare al singolo soggetto, come avveniva nelle forme virtuose epistolari. Questa personalizzazione della didattica è un cambio di prospettiva che è stato decisamente anticipato dai filosofi Gilles Deleuze e Félix Guattari nel libro L'anti-Edipo (20/4), dove sostanzialmente alla oggettività dei bisogni, riflesso di una società meccanica, gli studiosi contrappongono la soggettività dei desideri, specchio di una cultura stratificata, modificata dai media.

Noi viviamo ancora oggi in una società postmoderna, dove al modello impersonale di un soggetto inteso come moltitudine, si affianca un soggetto complesso, fragile e diverso.

La didattica del disegno, come delle altre discipline, non può fare a meno di comprendere la complessità dei soggetti che formano una classe e conseguentemente una società. Personalizzare e, parallelamente, cercare gli elementi universali sarà la sfida che la didattica del disegno dovrà affrontare nei prossimi anni [Strollo 2008].

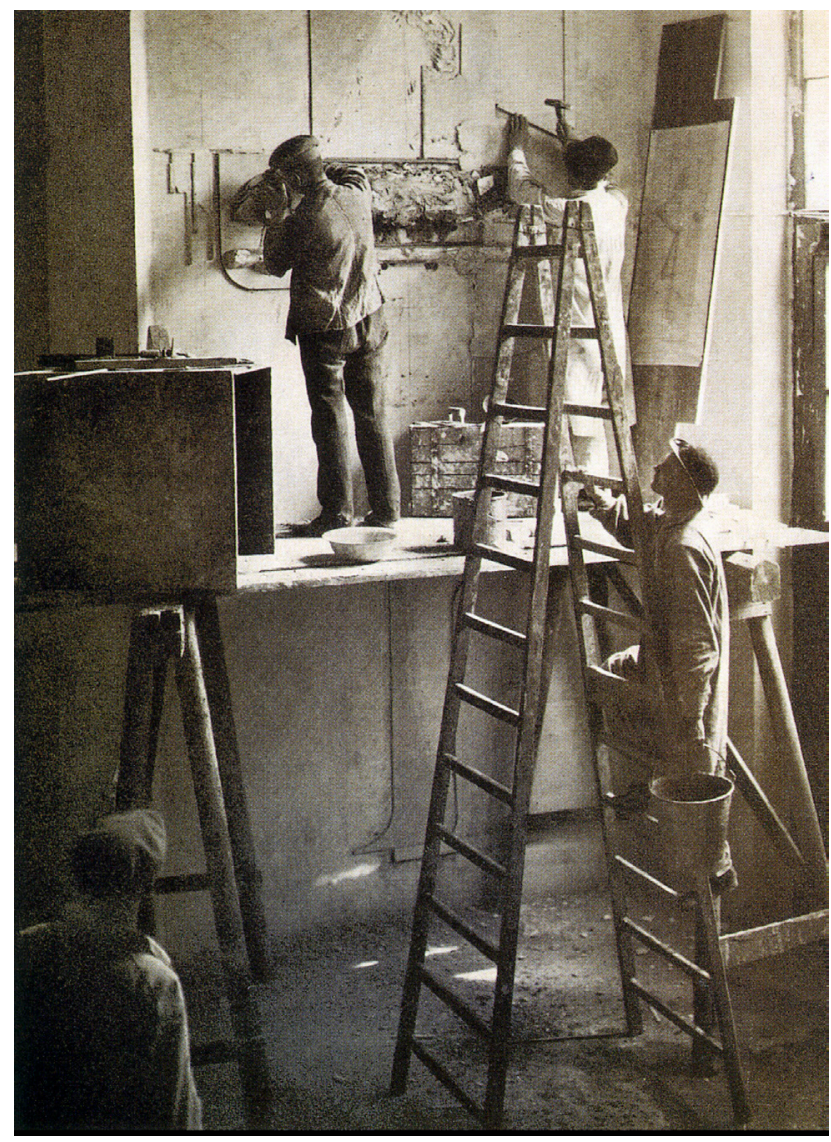


Fig. 7. Raffronto fra un ambiente fisico e uno virtuale per la didattica del disegno.

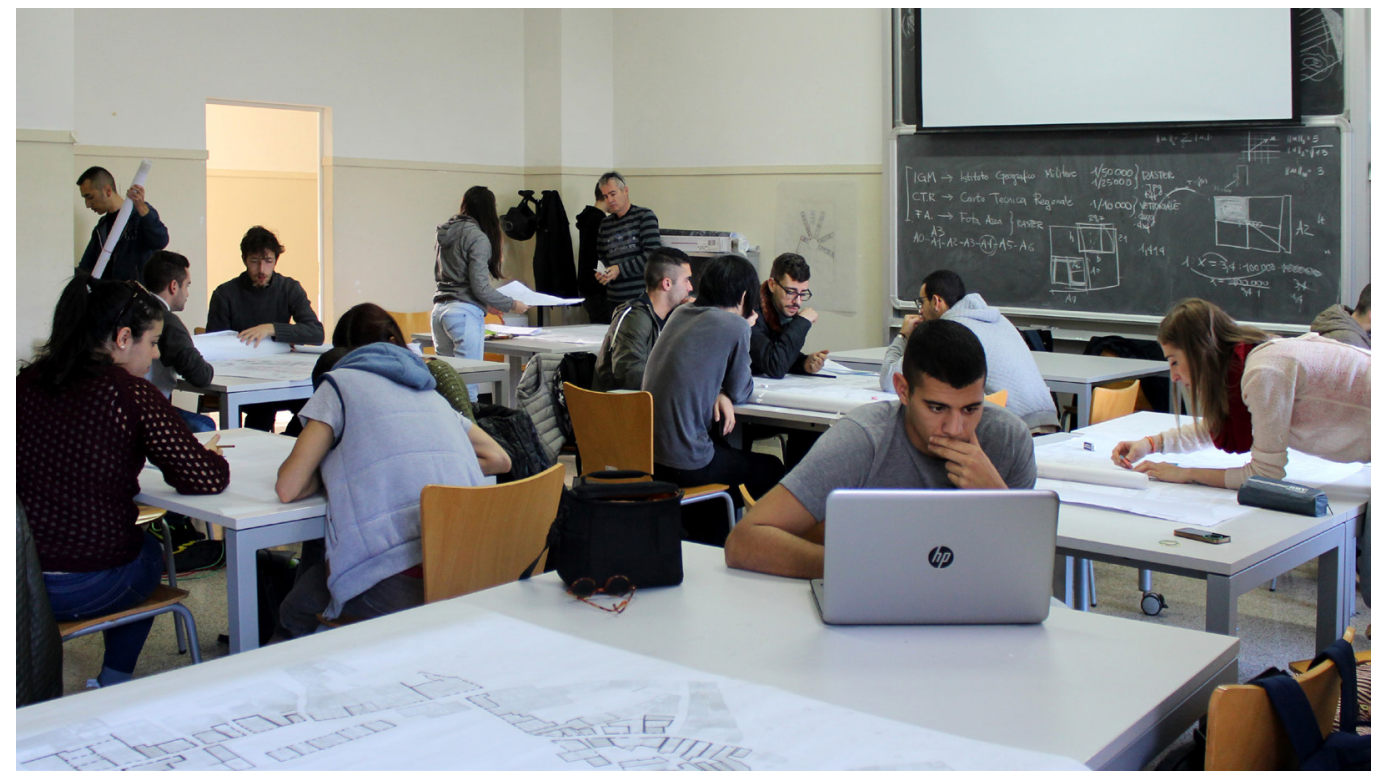

\section{Conclusioni}

Come acutamente sostenuto da Tomás Maldonado nel libro Critica della ragione informatica (1999): bisogna superare le retoriche della 'tecnofobia' e della 'tecnofilia', cercando di far dialogare gli statuti fondativi delle discipline con le evoluzioni e le dinamiche della società, costruendo un ambiente vivo e aperto in grado di co-evolvere costruttivamente.

Non dobbiamo dimenticare la filosofia di John Dewey, il pedagogo americano che aveva elaborato il concetto di esperienza intesa come strumentalismo. II soggetto è immerso in un ambiente sociale di cui si nutre e cresce con esso. L'esperienza educativa avviene nel momento in cui l'individuo espande la propria sfera di conoscenza [Dewey 20I4]. Oggi possiamo asserire che è fondamentale implementare le due esperienze, quella del soggetto immerso in un ambiente fisico e sociale attivo e quella della comunità virtuale che travalica lo spazio e il tempo tradizionali. In tal modo il soggetto amplia la propria conoscenza mediante un sistema complesso di interazione con una comunità fisica e virtuale [Virilio 1998], in cui sia possibile implementare le esperienze delle diverse modalità di apprendimento.

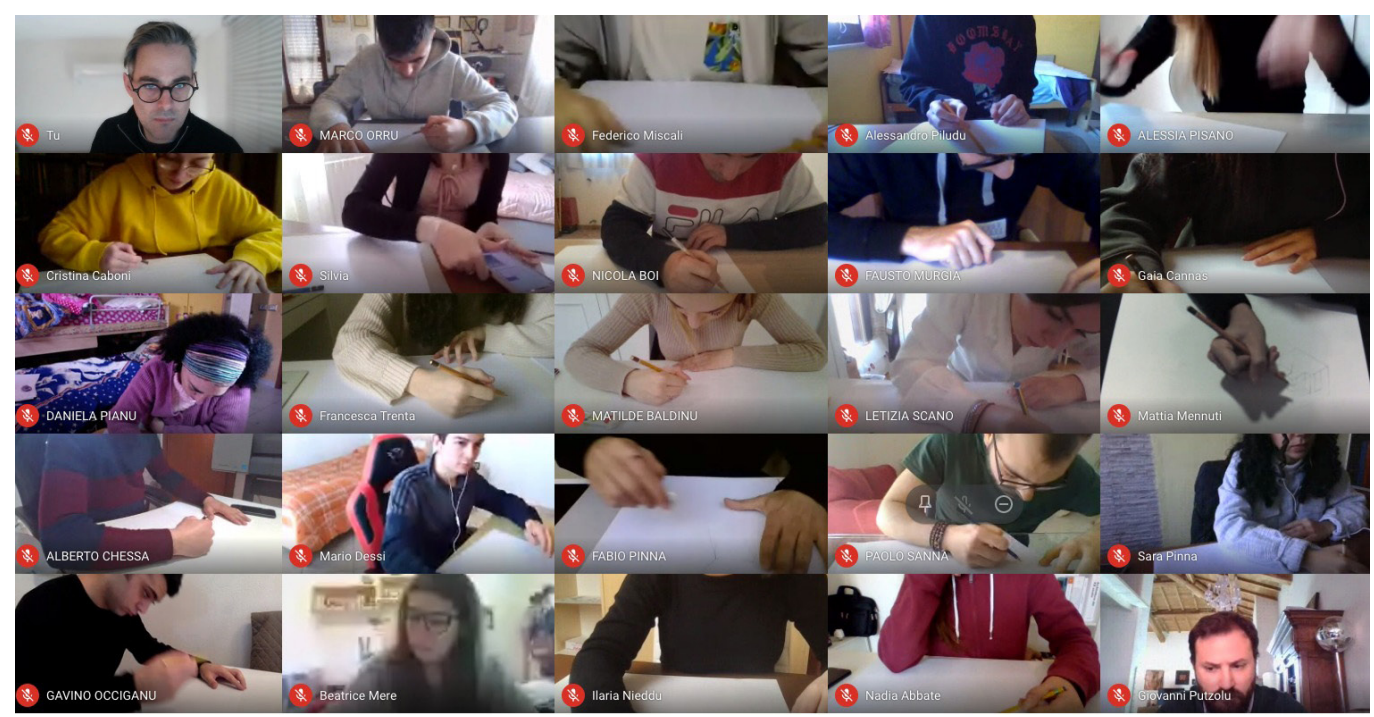


Come illustrato precedentemente, la formazione a distanza ha avuto molteplici forme e diverse applicazioni sin dai tempi antichi. Le tecnologie informatiche e digitali, che si sono sviluppate negli ultimi decenni, hanno ovviamente implementato le potenzialità insite in questa pratica antica e spingono la disciplina del disegno e della rappresentazione a mettere in campo una teoria della didattica in grado di incorporare le innovazioni sociali e tecniche. L'obiettivo è formare uno studente sempre più attrezzato, fornendo sia gli strumenti grafici sia le conoscenze teoriche e pratiche del disegno.

\section{Riferimenti bibliografici}

Aristotele (2015). Retorica ad Alessandro (M. F. Ferrini, a cura di). Milano: Bompiani.

Benjamin W. (1974). L'opera d'arte nell'epoca della sua riproducibilità tecnica:Arte e società di massa. Torino: Einaudi.

Bettinelli E., Castiglioni A. ( 1987). Oggetto e progetto: Dal disegno al comportamento utopico. Milano: FrancoAngeli.

Boito C. (1988). I principii del disegno e gli stili dell'ornamento. Milano: Cisalpino-La Goliardica. [Prima ed. I principii del disegno e gli stili dell'ornamento: Lettere. Milano | 882].

Calvani A., Rotta M. (2000). Fare formazione in internet: Manuale di didattica online. Trento: Erickson.

Cicalò E. (2020). The Elements of Drawing by John Ruskin. Drawing between Art, Science, Design and Education in XIX century in England. In diségno. n.6, pp. 205-212.

Cicoli F., Moretti F. (a cura di). (2017). Aristotele, Sull'impero: Lettera ad Alessandro. Milano: Mimesis.

Craft C. (2012). An audience of artists: Dada, neo-dada, and the emergence of abstract expressionism. Chicago: University of Chicago Press.

Deleuze G., Guattari F. (20|4). L'anti-Edipo: Capitalismo e schizofrenia. Milano: Fabbri.

Dewey J. (20|4). Esperienza e educazione. Milano: Raffaello Cortina Editore.

Garrison D. R. (1985). Three generations of technological innovations in distance education. In Distance education, n.6 (2), pp. $235-24 I$.

Maldonado T. (1999). Critica della ragione informatica. Milano: Feltrinelli.

Nipper S. (1989). Third generation distance learning and computer conferencing. In Mindweave: Communication, computers and distance education, n. pp. 63-73.

Pinotti A., Somaini A. (20 I6). Cultura visuale: Immagini, sguardi, media, dispositivi.Torino: Einaudi.

Pitman I. ( 840$)$. Phonography: Or Writing by sound; being a natural method of writing, applicable to all languages, and a complete system of short hand. London: Samuel Bagster \& Sons.

Ruskin J. (2009). Gli elementi del disegno. Milano: Adelphi. [Prima ed. The Elements of Drawing; in three letters to beginners. London 1857].

Schonberg A., Kandinsky W. (20 I 8). Musica e pittura (Hahl-Koch J., a cura di). Milano: Abscondita.

Strollo R. M. (2008). L'insegnamento del disegno nella formazione a distanza: una sfida educativa. In Strollo R. M. (a cura di). Rappresentazione e formazione:Tra ricerca e didattica. Roma: Aracne.

Tury S., Robinson L., Bawden D. (20I5). The information seeking behaviour of distance learners: A case study of the University of London international programmes. In The journal of academic librarianship. n. 4 I (3), pp. 3I 2-32I.

Verduin J. R., ClarkT.A. (199I). Distance education:The foundations of effective practice. San Francisco: Jossey-Bass.

Virilio P. (1998). Lo spazio critico. Bari: Dedalo.

\section{Autori}

Michele Valentino, Università degli Studi di Sassari, mvalentino@uniss.it

Enrico Cicalò, Università degli Studi di Sassari, enrico.cicalo@uniss.it

Marta Pileri, Università degli Studi di Sassari, marta.pileri@gmail.com

Per citare questo capitolo:Valentino Michele, Cicalò Enrico, Pileri Marta (2021). Dalla didattica epistolare alla didattica digitale. Tradizione e attualità dell'apprendimento a distanza del disegno/From epistolary to digital teaching. Tradition and relevance of distance learning of drawing. In Arena A., Arena M. Mediati D. Raffa P. (a cura di). Connettere. Un disegno per annodare e tessere. Linguaggi Distanze Tecnologie. Atti del $42^{\circ}$ Convegno Internazionale dei Docenti delle Discipline della Rappresentazione/Connecting. Drawing for weaving relationship. Languages Distances Technologies. Proceedings of the $42^{\text {th }}$ International Conference of Representation Disciplines Teachers. Milano: FrancoAngeli, pp. $1832-1847$. 


\title{
From Epistolary to Digital Teaching. Tradition and Relevance of Distance Learning of Drawing
}

\author{
Michele Valentino \\ Enrico Cicalò \\ Marta Pileri
}

\section{Abstract}

In this phase of international crisis due to the pandemic, the discipline of drawing wonders how to transmit knowledge. Distance university teaching, which in this phase has become the only form of sharing knowledge, has led scholars and teachers of drawing to develop new methodologies capable of triggering an ever-increasing degree of awareness in the student's mind. This essay intends to offer an overview of the historical evolution of distance learning, which in ancient times, and until the nineteen centuries, took place through the form of the epistolary letter. In the twentieth century, through new media, it is transformed into an increasingly complex and effective system of knowledge implementation. The revolution took place starting from the nineties of the last century when computer networks create an acceleration of the communication tools of knowledge. This intense transformation of knowledge and transmission thanks to the network and digital has led scholars of communication, social sciences and, of course, drawing and representation to build new practices and methodologies capable of offering an increasingly active and interacting field of experiences and learning in an increasingly open and codified system that allows creating an augmented knowledge. In this revolution in the means of transmitting knowledge of drawing, both face-to-face and remote laboratory experiences must be implemented, capable of building an increasingly complex learning community.

Keywords

drawing, teaching, methodologies, media, historical evolution.

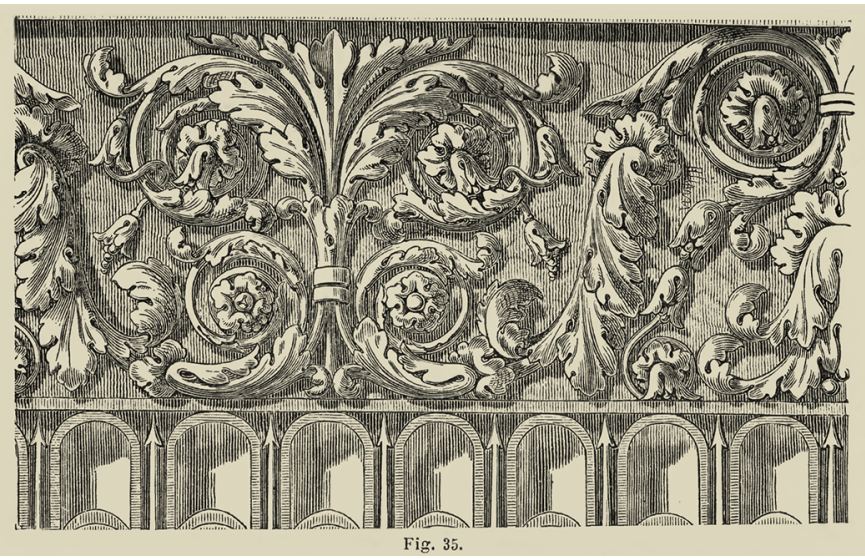




\section{Three generations of distance learning}

Distance learning aims to overcome the space-time limits typical of face-to-face training. Its use has had a growth influenced by the implementation of communication technologies. This type of training has a wide range of applications and has used a large variety of media in different contexts [Verduin 199I]. The periodization of the three generations of distance learning firstly proposed by Donn Randy Garrison [Garrison 1985] and then further consolidated by Søren Nipper [Nipper 1989] is now commonly accepted.

The first generation - of nineteenth-century origin- is linked to postal correspondence. The second -attributable to the sixties and seventies of the twentieth century- is related to audio-visual technologies. While the third makes use of technologies and computer networks. But it is precise with the pandemic emergency that distance learning has received a significant boost in its development and has forced the different learning communities to adopt it at the expense of the traditional one.

The coexistence of in-person and distance-learning didactic models has been witnessed since classical antiquity. The 'didactic' letters between Aristotle and Alexander the Great are proof of this. After the period of formation between 343 and 342 BC-years when at the invitation of Philip II of Macedonia took care of the education of the young prince-Aristotle dedicated a series of works to Alexander, whose originality is still controversial, such as the Retorica ad Alessandro Rhetoric to Alexander [Aristotele 2015] or the letter Sulla politica delle città [Aristotele 20 17]. Thus outline the simultaneous presence of peripatetic and epistolary education.

Much closer to us, albeit not with a didactic intent but to structure a common knowledge and an aspiration towards the profound renewal of art, it is possible to cite as an example the correspondence between Vasily Vasil'evič Kandinskij and Arnold Schönberg, collected in the text Musica e pittura [Schonberg 20 18]. Similarly, in his work I Principii del Disegno e gli Stili dell'Ornamento (The Drawing Principles and the Ornament Styles) [Boito 1988], published for the first time in 1882, Camillo Boito uses the epistolary form addressing his friend Giovanni, guiding him in his new position as a drawing teacher. In the twelve letters, the didactic methodology of drawing is the same as that of the other subjects taught in primary schools. About some of his friend's observations in the second letter, Boito states: "Teaching drawing is not an artistic teaching [...] Let's not confuse the education of taste with the teaching of drawing. [...] The beginning of the drawing study is already much nobler since the eye is intimately connected to intelligence" [Boito, 1988, pp. 7-9]. [Authors' translation from Italian]

When the movements between places were very slow, epistolary writing represented an extraordinary opportunity to communicate knowledge and experiences through a written form that spoke in the singular. Unlike traditional texts in which the author addresses a broad audience of readers and seeks a universal principle in writing, the letter contains a private message filled with the complexities of interaction between two subjects. It reflects a high degree of responsibility in the writer who communicates information and knowledge to a specific subject. Writing takes on an all-encompassing value.

It should remember that the first remote training, which goes beyond the epistolary one, dates to the years between the nineteenth and twentieth centuries, parallel to the devel-
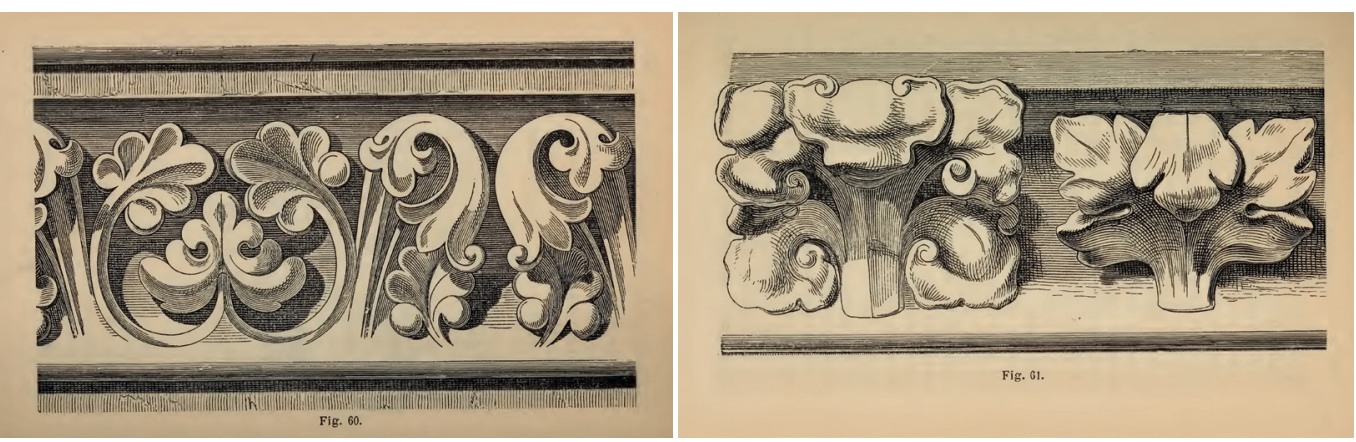
opment of the railway system. In this period, we are witnessing the birth of the first correspondence courses whose main objective is to educate all those who do not have access to an educational institution, which was then elitist.

In the nineteenth century, new forms of university teaching that used paper materials sent by post were born, and they were aimed to people who, for critical reasons, could not move to the centres for the dissemination of culture. Some examples are the correspondence courses of the developer of the famous shorthand system Isaac Pitman ( 1840). He had set the course remotely by sending texts by post transcribed in shorthand on postcards. A few years later, through the External Program established in 1858, the University of London gave birth to the first distance university course that led to today's more complex International Programs [Tury Robinson 2015].

Furthermore, one cannot fail to mention The Elements of Drawing ( 1857 ) by John Ruskin, conceived as a support for distance learning, with numerous references to supplementary teaching materials that the student could consult independently. The manual written for amateur drawing learning is structured in three letters generically addressed to the reader [Cicalò 2020]. The English theorist, from the first letter, makes known the intentions of the book: "My dear reader, [...]. If you desire only to possess a graceful accomplishment, to be able to converse in a fluent manner about drawing, or to amuse yourself listlessly in listless hours, I cannot help you: but if you wish to learn drawing that you may be able to set down clearly, and usefully, records of such things as cannot be described in words, [...] then I can help you, or, which is better, show you how to help yourself.' [Ruskin I857, pp. I-2].

These first examples constitute a teaching model of unidirectional 'instructionism' from teacher to learner.

Then, various distance training programs for postal correspondence are developed during the first half of the twentieth century. A well-known Italian example is the establishment of the Scuola Radio Elettra in 195I, intended as a theoretical-practical professional training centre oriented to the world of work.

The change of perspective took place in the sixties and seventies of the twentieth century with the entry of new media into mass culture. Television introduces a screen, a window, into homes, allowing distances to break down and generate new narratives. Art, think of Robert Rauschenberg's Neo-Dada movement, had layered messages from new media on a canvas in a simultaneous narrative of information. In the seventies, it is video art that definitively broke the relationship with the traditional materials of art, introducing a political vision that pushed the observer to become aware of the crises of his time [Craft 20 I2].

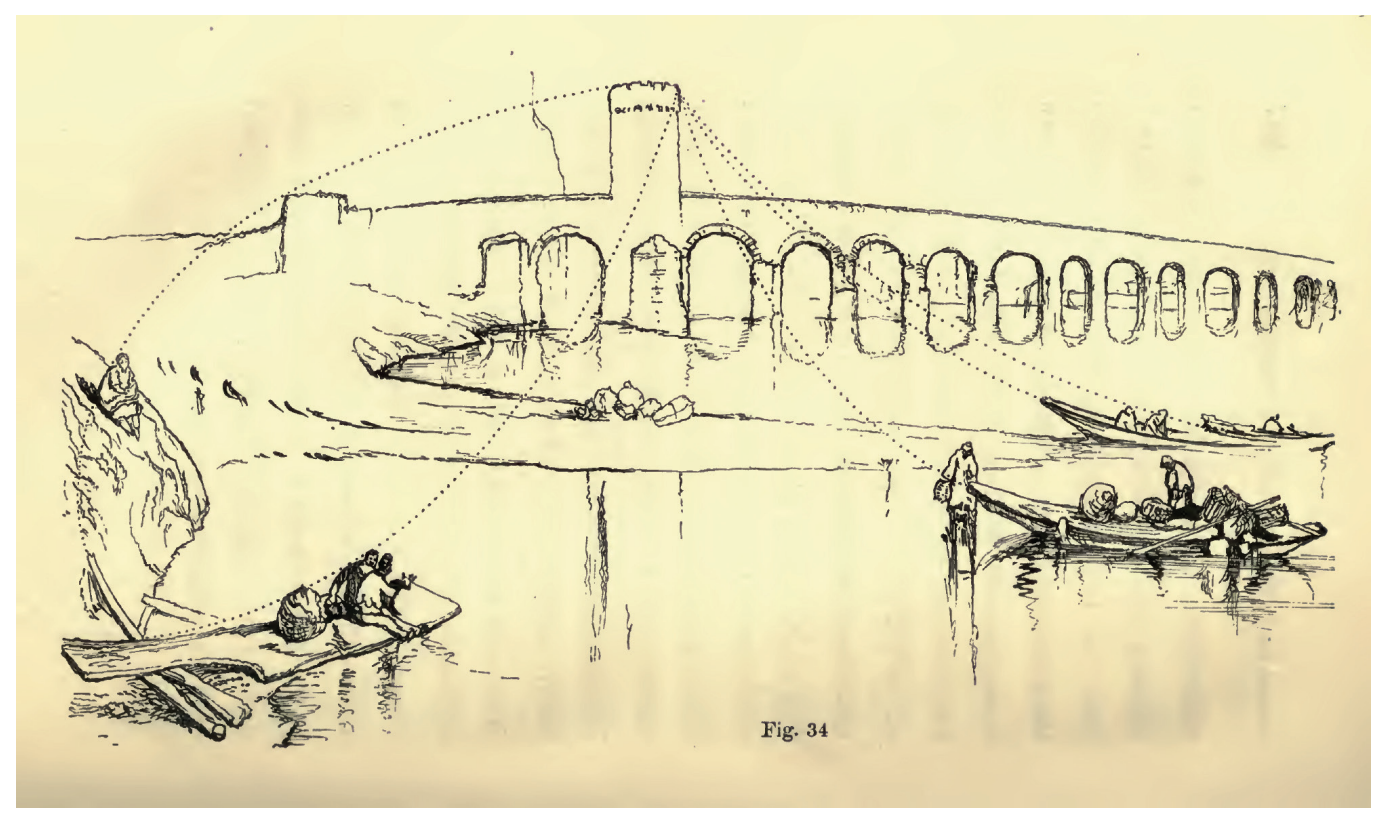


Distance learning, through the new media, becomes an extraordinary tool for the transmission of knowledge. The subject finds himself immersed in a new depth capable of enhancing individual experiences.

In these years, the first programs broadcast via radio and television developed with the aim to educate the masses. Just think of the famous television show Non è mai troppo tardi conducted by teacher Alberto Manzi, broadcast by Rai (1960-1968). The aim was to transmit a primary education course for illiterate people in the inclusion and modernization of the entire Country.

Over time, these practices become increasingly sophisticated through a methodology and a pedagogical philosophy focused on communication effectiveness. In the nineties, universities promoted television training programs, broadcast in the night schedule, as the UniNettuno educational courses, among which the course Disegno e Architettura Tecnica with the video lessons of Professor Michele Inzerillo on the basics of descriptive geometry. It witnessed the transition from the educational model based on 'instructionism' to interactive 'constructionism' [Pinotti 2016].

The digital revolution, in the nineties, generated an acceleration in the transmission of knowledge and learning. Various tools are available in the hands of teachers to clarify the topics, with the possibility of going deeper and deeper into a multitude of didactic folds. Just consider the countless interactive resources now available on the web. The possibility for the student to access lessons on digital platforms and find tutorials on virtual channels, more and more responsive to individual needs, has created a unique learning environment. Think of the various lessons available on YouTube channels that allow you to deepen your knowledge of the most varied software for digital representation. These systems are built-in real-time and allow for the implementation of information that can be added progressively. With the beginning of the new millennium, social constructivism theories are applied to cognitive virtual environments that generate multiple knowledge systems. These involve users in increasingly multidirectional learning [Calvani 2000].

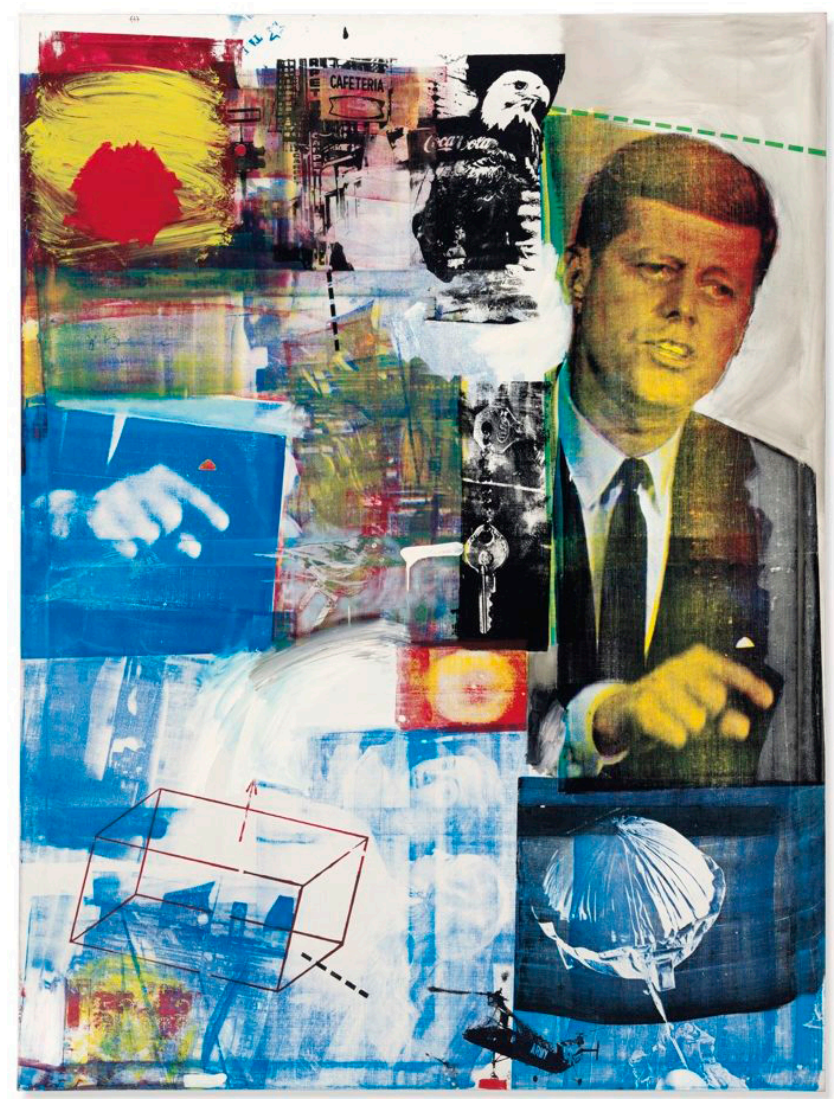




\section{Criticalities and potentialities of distance learning}

In modernity, the founding core of training takes place in the atelier, think of the Bauhaus school (1919-1933) or the Vchutemas (1920-1927), where knowledge is realized in a direct experience between the teacher and the students. The atelier is an alchemical place where you can experience the complex network of interrelationships of experiences between a 'recognized' teacher and highly motivated students [Bettinelli 1987].

In the same years, Benjamin understood that the reproductive means of images would inevitably change the future time. In his book, The Work of Art in the Age of Mechanical Reproduction (1936), he had understood that the modern techniques of photography and cinema would have undermined the aura of the authenticity of the work and offered an extraordinary tool for the democratic dissemination of knowledge.

It is known that history has experienced crises caused by wars and pandemics that have undermined the conditions of prosperity, creating social, economic, and political tensions. These crisis conditions generate in the present new responses in the fields of philosophy, literature, and art. Just think of the artistic movements that developed during the First World War.Today, the pandemic forces a general rethinking of how knowledge is transmitted.

The teacher must be able to clarify and communicate an exact, precise and transmissible disciplinary message. Compared to face-to-face teaching, in which the physical interaction of bodies makes it possible to make different verbal and bodily expressions explicit, remote education has proved effective when the teacher capitalizes on time. The pandemic, which generates isolation, pushes the individual to achieve a degree of concentration and punctuality. Often, the frontal teaching, precisely because it is taken for granted, does not allow achievement. Thus, distance teaching can create a closer relationship between the teacher and the individual student, generating better results than in the presence.

Also, the teaching of drawing, with all its semantic complexity of the communication of meanings and messages, becomes a field of action to experiment with new forms of transmission of knowledge. In a state of crisis, the experience of distance learning has undoubtedly led the teacher to question the time factor. But as in every moment of crisis, new questions arise about the future. In this regard, training linked to the discipline of drawing must question the modalities and disciplinary and methodological prerogatives.

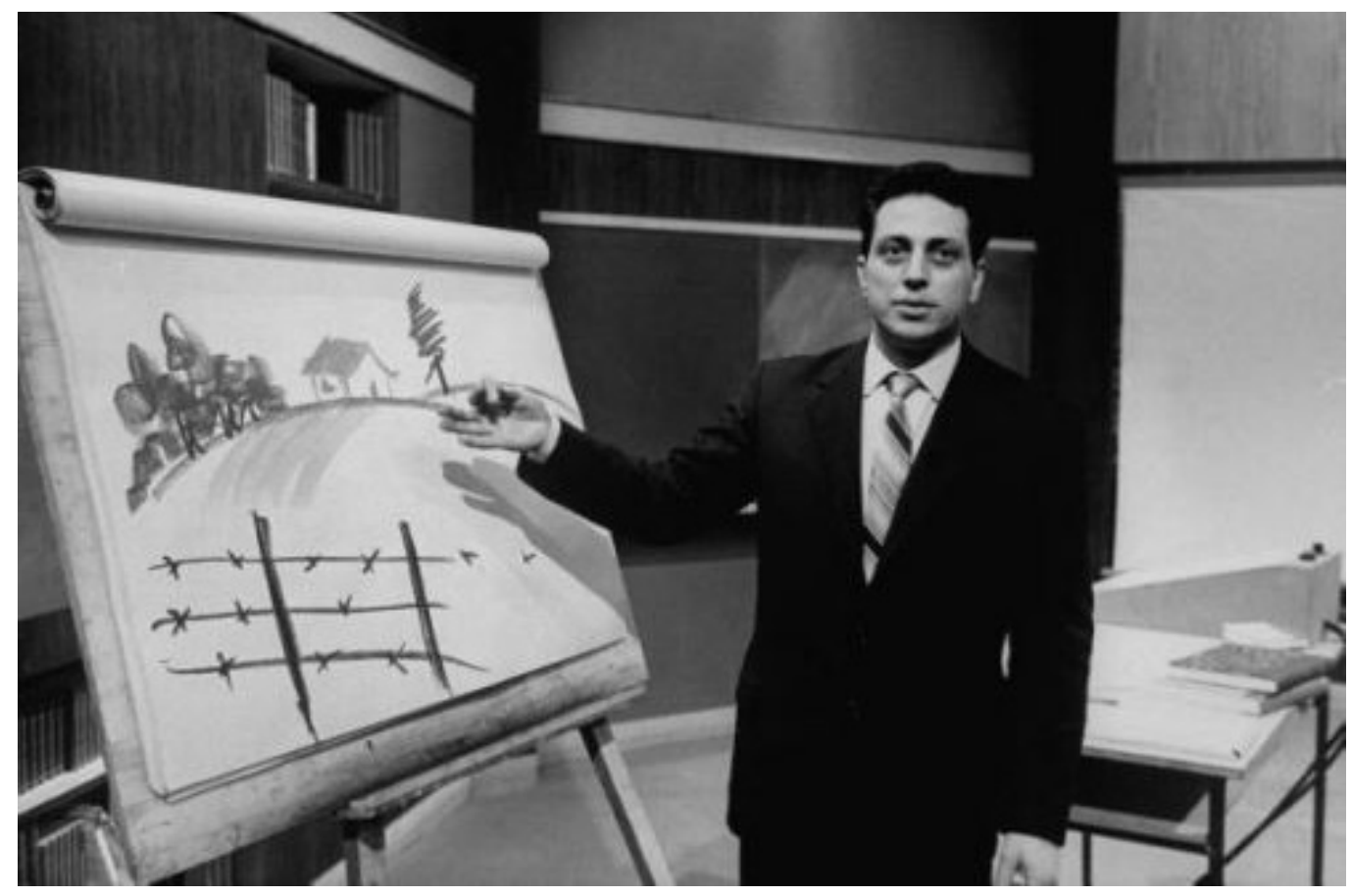


The possibility for the student to access lessons on digital platforms and find tutorials on virtual channels, more and more responsive to individual needs, has created a unique learning environment. Think of the various lessons available on YouTube channels that allow you to deepen your knowledge of the most varied software for digital representation.

Fortunately, every moment of crisis has been accompanied by a moment of rebirth in history. A resurgence that is almost never made of an overcoming of the past, but of recovery and contamination of the present with the future. It follows that, once the pandemic crisis has been overcome, the discipline of drawing can question its internal statutes by enhancing the qualities that have also developed through distance learning. It is necessary to integrate different means of transmission of knowledge: the workshop as experiential moment and didactics through video - which strives in a dialogical way to speak to the individual subjectas happened in the virtuous forms of letters. This personalization of didactics is a change of perspective that the philosophers anticipated Gilles Deleuze and Félix Guattari in the book L'anti-Edipo (Anti-Oedipus)(20I4), where scholars essentially contrast subjectivity to the objectivity of needs, a reflection of a mechanical society of desires, a mirror of a stratified culture, modified by the media.

We still live today in a postmodern society, where the impersonal model of a subject understood as a multitude is accompanied by a complex, fragile and different issue.

The teaching of drawing, like other disciplines, cannot help but understand the complexity of the subjects that make up a class and consequently society. Customizing and, at the same time, seeking universal elements will be the challenge that drawing education will have to face in the coming years [Strollo 2008].

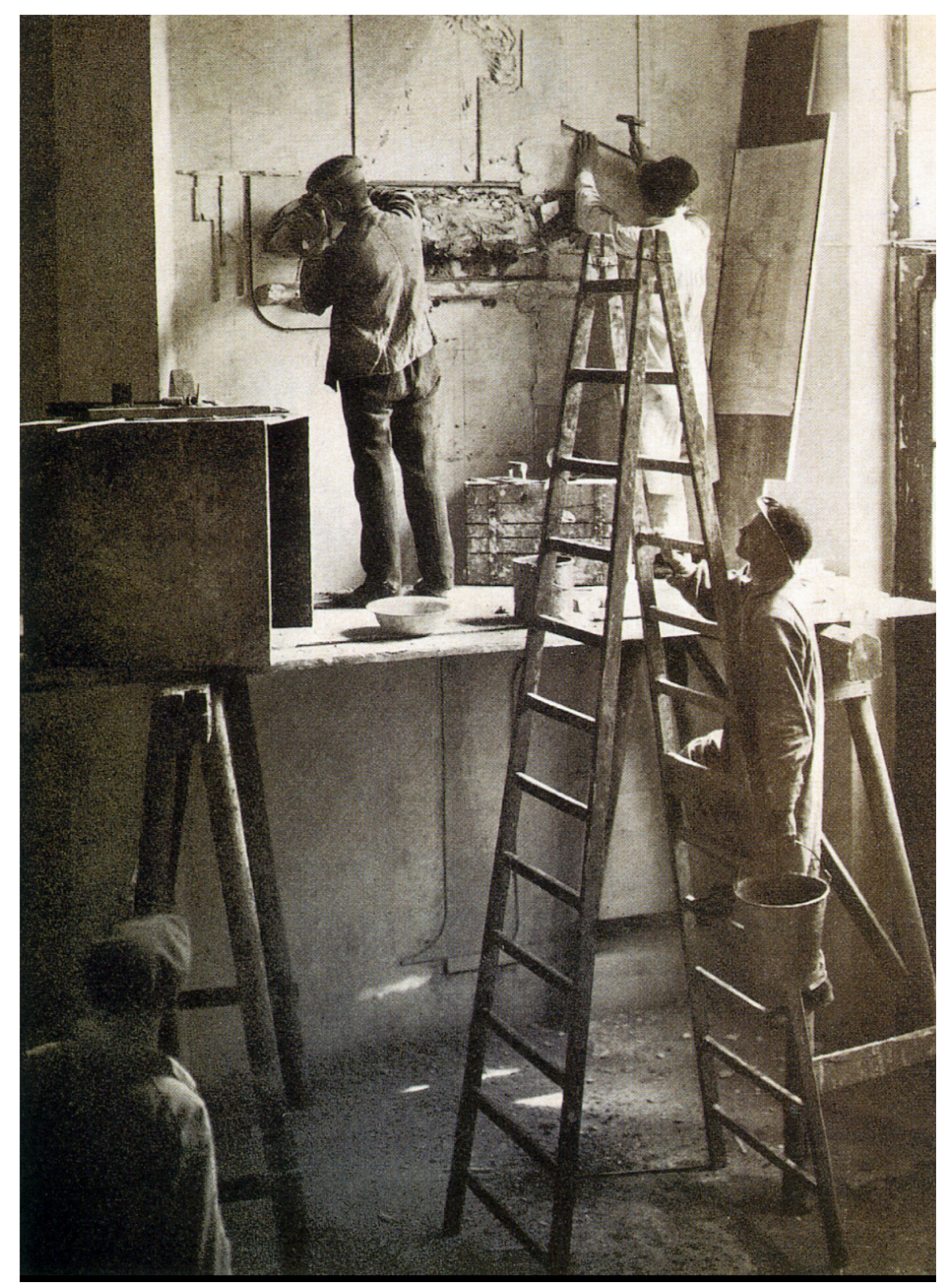


Fig. 7. Comparison between a physical and a virtual environment for teaching drawing.
Fig. 8. Comparison between a physical and a virtual environment for teaching drawing.



\section{Conclusions}

As acutely argued by Tomás Maldonado in the book Critica della ragione informatica (Critique of computer reasoning) (1999): we need to overcome the rhetoric of 'technophobia' and 'technophilia', trying to make the founding statutes of the disciplines dialogue with the evolutions and dynamics of society, building a living and open environment capable of constructively co-evolving.

We must not forget John Dewey's lesson. The American pedagogue developed and introduced the concept of experience understood as instrumentalism. According to his theory, the subject is immersed in a social environment with which he feeds and grows it. The educational experience occurs when the individual expands his or her sphere of knowledge [Dewey 2014]. Today we can assert that it is essential to implement the two experiences, that of the subject immersed in an active physical and social environment and that of the virtual community beyond traditional space and time. In this way, the subject expands his knowledge through a complex interaction system with a physical and virtual community [Virilio 1998]. It is possible to implement the experiences of the different learning modes.

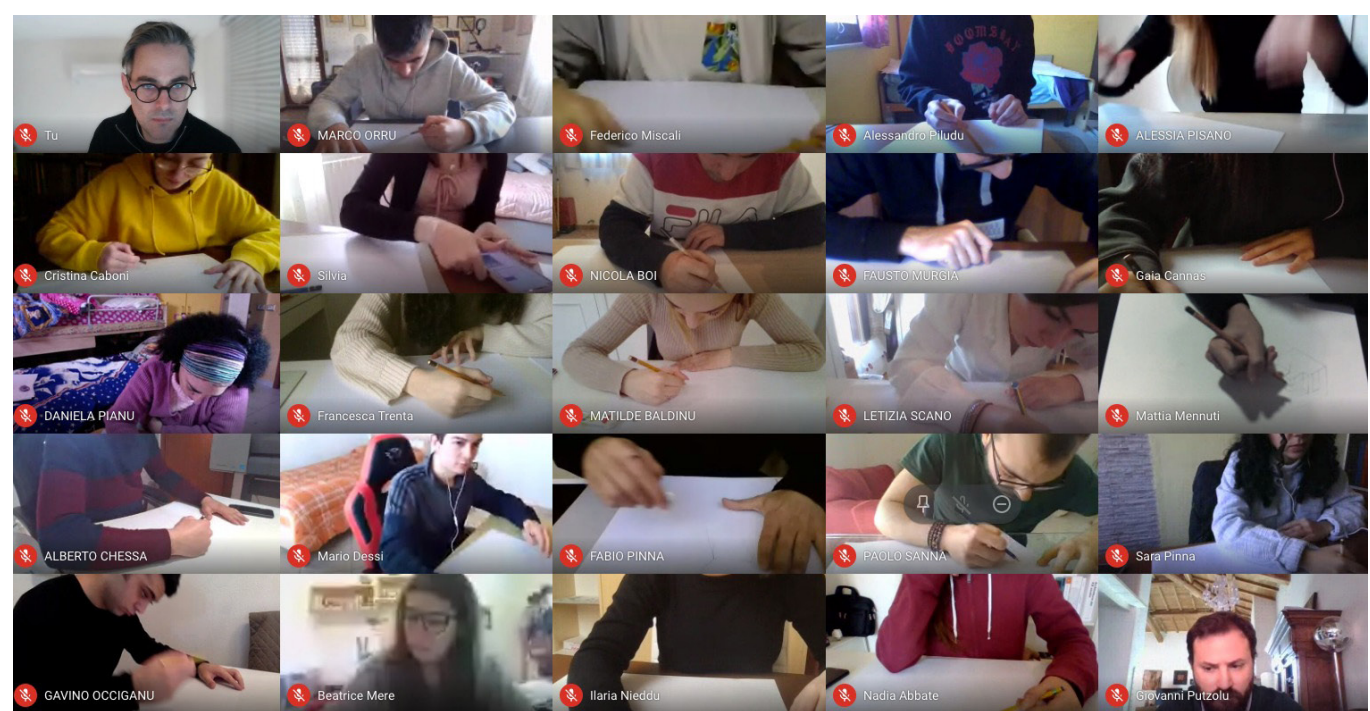


As shown above, distance learning has had many forms and different applications since ancient times. Information and digital technologies, which have developed in recent decades, have implemented the potential inherent in this ancient practice and push the discipline of drawing and representation to field a teaching theory capable of incorporating social and technical innovations. The goal is to train an increasingly equipped student, providing both graphic tools and theoretical and practical knowledge of drawing.

\section{References}

Aristotele (20 I5). Retorica ad Alessandro (M. F. Ferrini, a cura di). Milano: Bompiani.

Benjamin W. (1974). L'opera d'arte nell'epoca della sua riproducibilità tecnica: Arte e società di massa. Torino: Einaudi.

Bettinelli E., Castiglioni A. ( 1987). Oggetto e progetto: Dal disegno al comportamento utopico. Milano: FrancoAngeli.

Boito C. (1988). I principii del disegno e gli stili dell'ornamento. Milano: Cisalpino-La Goliardica. [Prima ed. I principii del disegno e gli stili dell'ornamento: Lettere. Milano | 882]

Calvani A., Rotta M. (2000). Fare formazione in internet: Manuale di didattica online. Trento: Erickson.

Cicalò E. (2020). The Elements of Drawing by John Ruskin. Drawing between Art, Science, Design and Education in XIX century in England. In diségno. n.6, pp. 205-212.

Cicoli F., Moretti F. (a cura di). (2017). Aristotele, Sull'impero: Lettera ad Alessandro. Milano: Mimesis.

Craft C. (2012). An audience of artists: Dada, neo-dada, and the emergence of abstract expressionism. Chicago: University of Chicago Press.

Deleuze G., Guattari F. (20|4). L'anti-Edipo: Capitalismo e schizofrenia. Milano: Fabbri.

Dewey J. (20|4). Esperienza e educazione. Milano: Raffaello Cortina Editore.

Garrison D. R. (1985). Three generations of technological innovations in distance education. In Distance education, n.6 (2), pp. 235-24l.

Maldonado T. (1999). Critica della ragione informatica. Milano: Feltrinelli.

Nipper S. (1989). Third generation distance learning and computer conferencing. In Mindweave: Communication, computers and distance education, n. pp. 63-73.

Pinotti A., Somaini A. (2016). Cultura visuale: Immagini, sguardi, media, dispositivi. Torino: Einaudi.

Pitman I. ( I 840). Phonography: Or Writing by sound; being a natural method of writing, applicable to all languages, and a complete system of short hand. London: Samuel Bagster \& Sons.

Ruskin J. (2009). Gli elementi del disegno. Milano: Adelphi. [Prima ed. The Elements of Drawing; in three letters to beginners. London 1857].

Schonberg A., Kandinsky W. (20 I 8). Musica e pittura (Hahl-Koch J., a cura di). Milano: Abscondita.

Strollo R. M. (2008). L'insegnamento del disegno nella formazione a distanza: una sfida educativa. In Strollo R. M. (a cura di). Rappresentazione e formazione:Tra ricerca e didattica. Roma: Aracne.

Tury S., Robinson L., Bawden D. (20I5). The information seeking behaviour of distance learners: A case study of the University of London international programmes. In The journal of academic librarianship. n. 4I (3), pp. 3I 2-32 I.

Verduin J. R., ClarkT.A. (199I). Distance education:The foundations of effective practice. San Francisco: Jossey-Bass.

Virilio P. (1998). Lo spazio critico. Bari: Dedalo.

Authors

Michele Valentino, Università degli Studi di Sassari, mvalentino@uniss.it

Enrico Cicalò, Università degli Studi di Sassari, enrico.cicalo@uniss.it

Marta Pileri, Università degli Studi di Sassari, marta.pileri@gmail.com

To cite this chapter. Valentino Michele, Cicalò Enrico, Pileri Marta (2021). Dalla didattica epistolare alla didattica digitale. Tradizione e attualità dell'apprendimento a distanza del disegno/From epistolary to digital teaching. Tradition and relevance of distance learning of drawing. In Arena A., Arena M., Mediati D., Raffa P. (a cura di). Connettere. Un disegno per annodare e tessere. Linguaggi Distanze Tecnologie. Atti del $42^{\circ}$ Convegno Internazionale dei Docenti delle Discipline della Rappresentazione/Connecting. Drawing for weaving relationship. Languages Distances Technologies. Proceedings of the $42^{\text {th }}$ International Conference of Representation Disciplines Teachers. Milano: FrancoAngeli, pp. I $832-1847$. 